International Business Management 13 (9): 371-380, 2019

ISSN: $1993-5250$

(C) Medwell Journals, 2019

\title{
Empirical Analysis of Triple Bottom Line Accounting on Corporate Profitability of Selected Oil Companies in Nigeria
}

\author{
${ }^{1}$ I.P. Onuoha and ${ }^{2}$ S.E. Emengini \\ ${ }^{1}$ Department of Accountancy, Business Administration and Banking/Finance, \\ Alex Ekwueme Federal University Ndufu, Ikwo, Ebonyi State, Nigeria \\ ${ }^{2}$ Department of Ac'countancy, University of Nigeria Nsukka, Enugu State, Nigeria
}

\begin{abstract}
This research work focused on the empirical analysis of triple bottom line accounting on corporate profitability of selected oil companies in Nigeria. The objective of this study is to empirically analyze the relationship between triple bottom accounting and the corporate profitability of selected oil companies in Nigeria. Specifically, this study intends to: ascertain the relationship between triple bottom line accounting and the corporate profitability of selected oil companies in Nigeria in respect to their Gross Profit Margin (GPM), Operating Margin (OM), Return on Assets (ROA), Return on Equity (ROE) and Return on Investment (ROI). This study employed a time series data spanning years 2000-2018. The methodology adopted in this research is the Ordinary Least Square (OLS) method of regression analysis and quasi experimental research design. Other methods of data analysis such as the cointegration test, Error Correction Modeling (ECM), LM serial correlation test, augmented Dickey Fuller test and Breusch-Pagan-Godfrey heteroskedasticity test, respectively was used to analyze the test statistics. Secondary data garnered from journal publications, test books and annual financial reports various years of the selected oil companies constitutes the sources of the data used in the analysis of this study. The population of this study constitutes 100 registered oil companies in Nigeria stock exchange while the sample size consists of top 10 oil companies in Nigeria which was selected using judgmental sampling technique. Multiple regression techniques and descriptive statistics and descriptive statistics were used in testing the hypothesis and analyzing the data, respectively. The study while employing various techniques of econometric analysis discovered the existence of a long-run relationship between triple bottom line accounting and corporate profitability. This implies that when companies are socially, environmentally and economically responsible to their host community or business environment, they stand the chance of enjoying an increase in profit and acceptance from their host communities. This study among others recommends the need for the host communities of firms, especially, oil companies and other stakeholders and well as governmental and non-governmental agencies to request for triple bottom line reports which meet their needs for information thus enabling them to be in a better position to hold companies to account for all the dimensions of triple bottom lines.
\end{abstract}

Key words: Triple bottom line accounting, operating margin, gross profit margin, return on equity, return on investment

\section{INTRODUCTION}

The notion of triple bottom line reporting has become increasingly fashionable in management and financial reporting circles over the last few years. The increase in global environmental awareness and the campaign for sustainable economic development are redirecting the attention of corporate businesses towards environmental sensitivity. The idea behind the triple bottom line paradigm emanates from the fact that a corporation's ultimate success should be measured not just by the traditional financial bottom line but also by its social/ethical and environmental performance. Of course, it has long been accepted by most people in and out of the corporate world that firms have a variety of obligations to stakeholders to conduct their businesses in a responsible manner. It is also an established fact that firms cannot be successful in the long run if they consistently disregard the interests of key stakeholders.

The concept of triple bottom line accounting, as proposed by Elkington, (1997) cited in Carlos, Lassala et al. (2017) places emphasis on three key aspects, these aspects according to Elkington should be put into consideration by corporate organization when embarking on their various business activities. These key indicators are people (social), profits (economic) and

Corresponding Author: I.P. Onuoha, Department of Accountancy, Business Administration and Banking/Finance, Alex Ekwueme Federal University Ndufu, Ikwo, Ebonyi State, Nigeria 
planet (environmental) which must be present in the business management. The above proposition suggest that a good business activity is one which understand the relationship between the people, corporate profitability and the environment as these three key aspect are essential in ensuring the safety of the people from hazards caused by the unsustainable use of the environment cum the long term existence of corporate organizations. This also suggests that corporate profitability should not be prioritized over the well being of the people and the environment, thus while aiming for profit it should be done in a manner that will not endanger the people and the environment. Triple bottom line can be defined as a framework for measuring and reporting corporate performance against economic, social and environmental performance. It is a catch phrase that is increasingly being used as a heuristic to help conceptualize sustainability as well as provide a framework for reporting against sustainability and environmental values and the three lines represent society, economy and the environments". Simply put, triple bottom line as a concept provides a framework through which the overall performance of a corporate entity is measured in relation to its economic, social and environmental performance. It is an umbrella term which captures social, environmental and economic value of an investment (Hammer and Pivo, 2017).

Kwaghman (2015) while buttressing the dangers associated with irresponsible behavior of corporate organizations opined that if businesses as a whole operates in a manner which causes damage to the society and there by causing a break down in the social harmony necessary to provide a stable context for operation then such business activities are neither economically nor socially sustainable. In the long run if business activities cause some level of damage to the ecosphere such that it cannot sustain human life on the scale we currently enjoy then it is clearly neither socially nor economically sustainable as there can be no economic activities let alone economic growth without human life to sustain it. Thus, corporate organizations should get more committed in the pursuance of the good of the society as these are essential in attaining her goal of profitability and long term existence.

Statement of problem: The problem of triple bottom line accounting does not lie with the amount of recognition given to the concept, rather it lies with its applicability in the attainment of people and environmental good (Hubbard, 2008). Given the importance of triple bottom line reporting to stakeholders and its effect on the corporate profitability of oil companies in particular, establishing these relationships is quite pertinent as it will enable oil companies and other corporate organizations to know that businesses exist to meet the people's needs and they will in turn enjoy the resulting rewards of profit; business organizations should also know that business can only thrive in a sustainable environment, thus, awakening the sense of social responsibility in them. There is also the problem of the issue of lack of uniformity of reports and difficulties encountered when trying to measure the three dimensions of the concept of the triple bottom line especially, the ecological bottom line.

Hence, the basic problem of this study is to determine whether a relationship exists between triple bottom line reporting and corporate profitability of selected oil companies in Nigeria. The study particularly intends to: ascertain the relationship between triple bottom line accounting and Gross Profit Margin (GPM), Operating Margin (OM), Return on Assets (ROA), Return on Equity (ROE) and Return on Investment (ROI) of selected oil companies in Nigeria. It is against this backdrop that the researcher is poised on empirically analyzing this study.

\section{Objective of the study:}

- Ascertain the relationship between triple bottom line accounting and Gross Profit Margin (GPM) of selected oil companies in Nigeria

- Evaluate the relationship between triple bottom line accounting and Operating Margin (OM) of selected oil companies in Nigeria

- Examine the relationship between triple bottom line accounting and Return on Assets (ROA) of selected oil companies in Nigeria

- Establish the relationship between triple bottom line accounting and Return on Equity (ROE) of selected oil companies in Nigeria

- Assess the relationship between triple bottom line accounting and Return on Investment (ROI) of selected oil companies in Nigeria

Statement of hypotheses: In view of the research objectives, the following research hypotheses have been formulated in their alternate form:

- $\mathrm{H}_{\mathrm{A} 1}$ : there is significant relationship between triple bottom line accounting and Gross Profit Margin (GPM) of selected oil companies in Nigeria

- $\mathrm{H}_{\mathrm{A} 2}$ : there is significant relationship between triple bottom line accounting and Operating Margin (OM) of selected oil companies in Nigeria

- $\mathrm{H}_{\mathrm{A} 3}$ : there is significant relationship between triple bottom line accounting and Return on Assets (ROA) of selected oil companies in Nigeria

- $\mathrm{H}_{\mathrm{A} 4}$ : there is significant relationship between triple bottom line accounting and Return on Equity (ROE) in Nigeria 
- $\mathrm{H}_{\mathrm{A} 5}$ : there is significant relationship between triple bottom line accounting and Return on Investment (ROI) of selected oil companies in Nigeria

Literature review: Many researchers have evaluated the relationship between triple bottom line accounting and corporate profit ability of oil companies in Nigeria from different perspectives.

Kwaghman, (2015) conducted a study on the impact of sustainability reporting on corporate performance of selected quoted companies in Nigeria, the researcher embarked on the research, so as ascertain the level of impact of sustainability reporting on return on equity of companies listed on the Nigeria stock exchange. The researcher adopted the use of ex-post facto as the design of the study. Based on the findings the researcher therefore recommended among others that firm should incorporate triple bottom line accounting in their reporting system.

Ho and Taylor, (2007) conducted a study on an empirical analysis of triple bottom-line reporting and its determinants: evidence from the United States and Japan. For the purpose of data analysis, regression was adopted, thus from the result obtained, the researchers found out among others that for total triple bottom line disclosure (integrating economic, social and ecological dimensions), the extent of reporting is higher for firms with larger size, lower profitability, lower liquidity and for firms with membership in the manufacturing industry. They added that the results for the total triple bottom line disclosure are primarily motivated by non-economic disclosures. The researchers also found out that the extent of general triple bottom line accounting is higher for Japanese firms with environmental disclosure being the central motivator. They concluded that the result obtained from the study could be attributed to the differences in national cultures, the regulatory environment and other institutional factors between the United States and Japan.

A study on the "Assessing the impact of triple bottom line reporting on problem of corporate sustainability in Nigeria", as conducted by Ijeoma (2014). The data obtained was analyzed using the Kruskal-Wallis rank sum test statistic. Based on the result of the data analyzed, the researcher found out among others that sustainability reporting contributes negatively on the problem of corporate sustainability by focusing on the environmental performance in Nigeria and also that triple bottom line disclosures in a company's financial statement improve employee motivation with a view to reduce labour turnover in Nigeria. Based on the findings of the study, the researchers recommended among others that regulatory bodies in Nigeria should develop more precise local guidelines for the measurement and disclosure of sustainability practices.
Ekwe et al. carried out a study on "triple bottom line accounting pattern and profitability of firms: an empirical study of oil and gas companies in Nigeria. The aim of the study was to ascertain the nexus between earning per share and cost incurred on social and environmental responsibility. The data for the study was collected from the annual reports of selected oil and gas industries and the financial statement of conoil and forte oil Nigeria Plc. The data were presented and analyzed, while the hypotheses were tested using the Ordinary Least Square (OLS). Based on the result obtained from the data analyzed the researchers discovered among others that, the application of triple bottom line reporting pattern in organizations would enable them report profitability accurately to stakeholders, measurement and allocation of environmental and social costs pertaining to the activities of the organization. Based on this, the researchers recommended among others that corporations should implement triple bottom line accounting patterns to enable them identify, measure and allocate environmental and social costs; and also, provide managers with strategies and techniques for managing performance across the three dimensions.

Suttipun, (2012) carried out a research on "triple bottom line reporting in annual reports: a case study of companies listed on the Stock Exchange of Thailand (SET). The objective of the study was to investigating narrative triple bottom line accounting in the annual reports of the top 50 largest Thai listed companies. To ascertain if there is any relationship between the extent of triple bottom line accounting and a variety of factors used in previous studies conducted in more developed countries, lastly, to conduct a comparison between of the findings of the study with findings reported in previous studies relating to triple bottom line accounting in third world countries. The study adopted the use of non-probability sampling method; the top 50 listed companies were sampled based on their 2010 annual reports. Thus, data obtained was analyzed using descriptive, multiple regression, independent samples t-tests and ANOVA. Based on the results obtained from the data analysis conducted the researcher found out among others that there are statistically significant differences between the triple bottom line accounting scores of high and low profile companies. In addition, there are statistically significant differences in accounting based on industry groups. The researcher added that although, the results did not indicate any relationship between triple bottom line disclosure scores and the various factors considered in previous studies. There was a correlation between the age, type of business and liquidity of companies and their economic information reporting score as well as between the size, risk and profitability of the company and the environmental 
information disclosure score. Different researchers have shown that the concept of triple bottom line reporting captures the essence of sustainability by measuring the impact of an organization's activities on the world including both its profitability and shareholder values and its social; human and environmental capital (Savitz, 2006). But unfortunately, the researcher could not find other prior studies that have been made so far which have dwelt on the relationship between these variables as used in this study, particularly in Nigeria.

\section{MATERIALS AND METHODS}

The methodology used in this work is Ordinary Least Square (OLS) method of regression analysis. This study adopts an expo-facto research design this research design is useful considering the fact that the researcher analyzed a time series data spanning from 2000-2018. This design according to Onwumere, relates to events that have already taken place. In an expo-facto research design, data is already in existence and no attempt is made to control or manipulate any of the independent variables, apparently because none of these variables are manipulatable. This design is appropriate for this study because it is not possible to directly manipulate or control any of the independent variables because the event have already taken place and therefore, the research is being conducted after the fact. This method is therefore, deemed appropriate for the conduct of this study as it will reveal the relationship between of triple bottom line accounting and the corporate profitability of selected oil companies in Nigeria.

Population and sample size: The population of this study is very vast and constitutes all the oil and gas companies quoted in Nigerian Stock Exchange (NSE) as at 2019 including those ones involved in onshore and offshore drilling and which have consistently prepared and submitted their annual reports from year 2000-2018. This is made up of 100 oil and gas companies as per the NSE fact book 2019. But because of the complexity and size of these oil and gas companies it is practically impossible to study the entire population in this work. So, the researcher has no option but to obtain a subset of the total population of the oil and gas companies which constitutes the sample size.

Sampling technique: The sampling technique adopted in the selection of the sample size of this study is known as judgmental sampling. Judgmental sampling is a non probability sampling technique where the researcher selects units to be sampled based on their knowledge and professional judgment. It can also be referred to as purposive or authoritative sampling and it is basically used in cases where the specialty of an authority can select a more representative sample that can bring more accurate results than by using other probability sampling techniques. The process involves nothing but purposely handpicking individuals from the authority or the researcher's knowledge and judgment.

The sample size of the study constitutes "top ten oil companies in Nigeria" which was selected using a judgmental sampling technique. The 10 selected oil companies are ranked as "top ten oil companies in Nigeria" because they are the top most and the biggest players and major shareholders in the oil and gas industry. Many of these oil and gas companies have branches in other parts of the world. The sample size of the study was designed in such a way that the corporate profitability of the ten oil companies in totality will be taken into consideration. The sample period is still the same with the population this is because this study is time series in nature, spanning year 2000-2018. The 10 selected oil companies ranked as "top ten oil companies in Nigeria" are listed in their order of ranking as follows: Exxon Mobil, Chevron Nigeria Limited, Shell Petroleum Development Company of Nigeria Limited. Statoil, Total Petroleum Nigeria Limited. Conoco Philips, Petrobras, Nexen Incorporated, Hardy Oil and Gas Plc and Addax Petroleum Nigeria Plc.

Determination of the research variable: The research variables employed in this study will be structured into dependent and independent variable for the purpose of the analysis.

Dependent variable: In this study, the Net Profit (NP) of the ten selected oil companies represents the dependent variable which is also the corporate profitability of the ten selected oil companies. The dependent variable will be used to regress against the independent variables.

Independent variables: The independent variable represents the corporate profitability ratios of the ten selected oil companies and which will be proxied as Gross Profit Margin (GPM), Operating Margin (OM), Return on Assets (ROA), Return on Equity (ROE) and Return on Investment (ROI) and which represents the factors arising from the corporate profitability of the ten selected oil companies i.e., the identified independent variables in this study represents major indices of the corporate profitability of the ten selected oil companies under review.

Model specification: The empirical analysis of the impact of triple bottom line accounting on corporate profitability of selected oil companies can be accomplished using a regression analysis which can be explicitly or implicitly 
stated based on a theoretical framework of endogenous models (King and Livine, 2004). Thus, the level of profitability of oil companies in Nigeria is assumed to be influenced by several variables of ' $\mathrm{Y}$ ' which represents the corporate profitability as the dependent variables and which will be proxied as the Net Profit (NP) of the selected oil companies in Nigeria. ' $\mathrm{X}$ ' on the other hand represents the independent variables and some factors arising from the corporate profitability of the ten selected oil companies and which will be proxied as Gross Profit Margin (GPM), Operating Margin (OM), Return on Assets (ROA), Return on Equity (ROE) and Return on Investment (ROI).

$$
Y=f(x)
$$

Where:

Y : The dependent variable (corporate profitability) and which was proxied as net profit of the selected oil companies

$\mathrm{X}$ : The independent variables and which were proxied as the factors arising from the corporate profitability of the ten selected oil companies (GPM, OM, ROA, $\mathrm{ROE}$ and ROI)

More specifically, Eq. 1 could be written in a non stochastic form as follows:

$$
\mathrm{NP}=\mathrm{f}(\mathrm{GPM}, \mathrm{OM}, \mathrm{ROA}, \mathrm{ROE} \text { and ROI })
$$

Where:

NP : The Net Profit

GPM : The Gross Profit Margin

$\mathrm{OM}$ : The Operating Margin

ROA : The Return on Assets

ROE : The Return on Equity

ROI : The Return on Investment

Therefore, we can re-write Eq. 2 in its stochastic explicit form based on the functional relation as follows:

$$
\mathrm{NP}=\mathrm{q}_{0}+\mathrm{q}_{1} \mathrm{GPM}+\mathrm{q}_{2} \mathrm{OM}+\mathrm{q}_{3} \mathrm{ROA}+\mathrm{q}_{4} \mathrm{ROE}+\mathrm{q}_{5} \mathrm{ROI}+\mathrm{U}_{\mathrm{t}}
$$

where all variables are as previously defined:

$\mathrm{q}_{0} \quad$ : The regression constants

$\mathrm{q}_{1}-\mathrm{q}_{5}:$ The parameter coefficients

Ut : The stochastic error term obtain:

Transforming Eq. 3 into a natural logarithm, we can

$$
\operatorname{InNP}=\mathrm{q}_{0}+\mathrm{q}_{1} \mathrm{IGPM}+\mathrm{q}_{2} \mathrm{OM}+\mathrm{q}_{3} \mathrm{ROA}+\mathrm{q}_{4} \mathrm{ROE}+\mathrm{q}_{5} \mathrm{ROI}+\mathrm{U}_{\mathrm{t}}
$$

Thus, the transformed log linear Eq. 4 will be estimated using the Ordinary Least Square (OLS) method of regression analysis. The use of log linear method improves the validity of the estimates. This method also reduces if not completely removes the hetrosdaciticy errors which may result from unsealed magnitude on both sides of the equation.

Nature and sources of data: The data source was entirely from secondary sources which were extracted from journal publications, text books and annual financial summary of selected oil companies in Nigeria. The data set for this study constitutes the annual time series data spanning from 2000-2018. Annual reports are generally, considered by management and outsiders to be the most important and influential source of corporate information (Beretta and Bozzollan, 2004; Ndukwe, 2009), Similarly, chief executive officers annual reports as major communication devices to both internal and external stakeholders concerning them and the corporate performance of their companies (Kwaghfan, 2015).

Techniques of data analysis: The statistical technique applied in analyzing the data is the multiple regression analysis. Multiple regression analysis is very relevant in investigating the predictable power of the independent variables on the dependent variable. The entire hypothesis was tested using the student t-statistics at $5 \%$ level of significance. E-View 9.0 econometric Software was utilized in the data analysis.

Data presentation, analysis and interpretation: augmented dickey fuller unit root test was used to test for the stationarity of each variable. The result of the co-integration test was reported next followed by the result of error correction modeling, the LM serial correlation test result was also conducted with the use of Breusch-Godfrey serial correlation LM test, finally, the heteroskedasticity test was conducted with the use Breusch-Pagan-Godfrey heteroskedasticity test result. The analysis is based on standard econometric techniques to verify the characteristics of each of the variables in the model and their long run relationships.

\section{RESULTS AND DISCUSSION}

Unit root test results: The use of time series data for estimating the parameters of economic relationship among variables is predicated upon some assumptions one of which is that such a data series is stationary. In this context, testing for stationarity or otherwise of the employed data sets becomes of essence in this analysis. Augmented Dickey-Fuller (ADF) was employed to test for the existence of unit roots in the data using trend and intercept. The test results are here presented. 
Int. Business Manage., 13 (9): 371-380, 2019

Table 1: ADF unit root result test at level and first difference (trend and intercept)

\begin{tabular}{|c|c|c|c|c|c|c|}
\hline \multirow[b]{2}{*}{$\underline{\text { Test/Variables }}$} & \multicolumn{2}{|l|}{ At levels } & \multicolumn{2}{|c|}{ First differences } & \multirow[b]{2}{*}{ Order } & \multirow[b]{2}{*}{ Remark } \\
\hline & t-statistic & Critical & t- statistic & Critical & & \\
\hline \multicolumn{7}{|l|}{$\overline{\mathbf{A D F}}$} \\
\hline $\mathrm{D}(\mathrm{NP})$ & -2.288634 & -3.052169 & -4.124928 & -3.081002 & $\mathrm{I}(1)$ & Stationary \\
\hline D(GPM) & 2.695291 & -3.081002 & -4.881201 & -3.098896 & $\mathrm{I}(1)$ & Stationary \\
\hline $\mathrm{D}(\mathrm{OM})$ & -2.129604 & -3.052169 & -4.047760 & -3.081002 & $\mathrm{I}(1)$ & Stationary \\
\hline $\mathrm{D}(\mathrm{ROA})$ & -2.687814 & -3.065585 & -5.479772 & -3.119910 & $\mathrm{I}(1)$ & Stationary \\
\hline $\mathrm{D}(\mathrm{ROE})$ & -2.450049 & -3.065585 & -4035707 & -3.065585 & $\mathrm{I}(1)$ & Stationary \\
\hline $\mathrm{D}(\mathrm{ROI})$ & -1.657024 & -3.052169 & -4.347632 & -3.065585 & $\mathrm{I}(1)$ & Stationary \\
\hline
\end{tabular}

Researcher's compilation from E-View (Version 9.0)

Table 2: Unrestricted cointegration rank test (trace)

\begin{tabular}{|c|c|c|c|c|}
\hline Hypothesized No. of CE(s) & Eigen value & Trace statistic & 0.05 critical values & Prob.** \\
\hline None* & 0.962674 & 262.2570 & 125.6154 & 0.0000 \\
\hline At most $1 *$ & 0.846101 & 150.4627 & 95.75366 & 0.0000 \\
\hline At most $2 *$ & 0.636165 & 86.83304 & 69.81889 & 0.0012 \\
\hline At most $3 *$ & 0.577741 & 52.45719 & 47.85613 & 0.0174 \\
\hline At most 4 & 0.372057 & 23.14451 & 29.79707 & 0.2390 \\
\hline At most 5 & 0.193734 & 7.324107 & 15.49471 & 0.5402 \\
\hline At most 6 & 7.31E-05 & 0.002484 & 3.841466 & 0.9579 \\
\hline
\end{tabular}

Trace test indicates 4 co-integrating equations at the 0.05 level; *denotes rejection of the hypothesis at the 0.05 level; **MacKinnon-Haug-Michelis (1999) p-values: Researcher`s compilation from E-View (Version 9.0)

Table 1 above, at $5 \%$ level of significance, none of the variables intended for this regression was stationary at level since by comparison, their critical values was greater in absolute values than their Augmented Dickey Fuller (ADF) test statistics that is $-2.288634<-3.052169$, $2.695291<-3.081002,-2.129604<-3.052169,-2.687814$ $<-3.065585, \quad-2.450049<-3.065585, \quad-2.076592$ $<-3.052169,-1.657024<-3.052169$. However, at first difference, all the variables which are NP, GPM, OM, ROA, ROE and finally, ROI became stationary, thus all the series (NP, GPM, OM, ROA, ROE and ROI) are stationary and integrated of the first order, I(1). Since, the variables are not stationary at level the Johansen cointegration was conducted to test for the long-run relationship.

Cointegration result: Cointegration was used to test for the long run relationship between the variables considered. For this purpose, the Johansen cointegration test was adopted. In Johansen's method, the eigen value statistic is used to determine whether co-integrated variables exist. Cointegration is said to exist if the values of computed statistics are significantly different from zero or if the trace statistics is greater in absolute value than the critical value at $5 \%$ level of significance. The model with lag 1 was chosen with the linear deterministic test assumption and the result is presented below (Table 2).

The results of the co-integration in the Table 2 indicated that the trace statistics is $>$ the critical value at 5 percent level of significance in four of the hypothesized equations. This confirms that there is at least four co-integrated long run relationship among the various variables used to model the relationship between monetary policy and economic growth in Nigeria for the period under study. Specifically, they are 262.2570 $>125.6154,150.4627>95.75366,86.83304>69.81889$ and 52.45719 $>47.85613$. Also, their p-value are $<0.05$ $(0.0000,0.0000,0.0012$ and 0.0174$)$, respectively. In other words, the null hypothesis of no cointegration among the variables is rejected. Hence, the test result reveals that there is the existence of a long-run equilibrium relationship in four co-integrating equations at $5 \%$ significance level. The normalized co-integrating coefficients for one co-integrating equation given by the long-run relationships are as follows:

$$
\begin{aligned}
& \mathrm{NP}=14.58792 \mathrm{GPM}+17.50944 \mathrm{OM}-0.938845 \mathrm{ROA}- \\
& 42.40643 \mathrm{ROE}+0.908389 \mathrm{ROI} \\
& \mathrm{SE}=(2.44733)(9.90167)(0.04700)(5.99964)(0.29359)
\end{aligned}
$$

where NP is the dependent variable, giving the coefficient of these variables and the signs they assumed; gross profit margin which is 14.58792 , operating margin was 17.50944 , returns on assets was -0.938845 , returns on equity was -42.40643 and finally, returns on investment was 0.908389 . The values in this relationship were extracted from the Johansen's cointegration test under the "normalized cointegration coefficients: 1 cointegrating equation" sub-section. They are coefficients showing the direction and strength of the relationship between the explanatory variables and dependent variable in the long-run; the extracted coefficients shows that gross profit margin, operating margin and returns on investment had a positive and strong relationship at the long run while returns on assets and returns on equity had a negative relationship with explanatory variable. 
Int. Business Manage., 13 (9): 371-380, 2019

Table 3: ECM result

\begin{tabular}{|c|c|c|c|c|}
\hline Variable & Coefficient & SE & t-statistic & Prob. \\
\hline$\overline{\mathrm{C}}$ & 7446.579 & 3545.338 & 2.100386 & 0.0738 \\
\hline GPM & 0.014131 & 0.026030 & 0.542865 & 0.6041 \\
\hline $\mathrm{OM}$ & 0.544606 & 0.215022 & 2.532792 & 0.0208 \\
\hline ROA & 0.432102 & 0.158300 & 2.729639 & 0.0160 \\
\hline ROE & 1.266759 & 0.475621 & 2.663379 & 0.0029 \\
\hline ROI & 389.3445 & 198,7032 & 1.959428 & 0.8736 \\
\hline ECM(-1) & -0.532745 & 0.175321 & -3.038683 & 0.0052 \\
\hline $\mathrm{R}^{2}$ & 0.950013 & Mean dependent var & 26827.41 & \\
\hline Adjusted $\mathrm{R}^{2}$ & 0.900027 & SD dependent var & 10830.09 & \\
\hline SE of regression & 3424.314 & Akaike info criterion & 19.41972 & \\
\hline Sum squared resid & 82081487 & Schwarz criterion & 19.79734 & \\
\hline Log likelihood & -137.6479 & Hannan-Quinn criter. & 19.41569 & \\
\hline F-statistic & 19.00538 & Durbin-Watson stat & 1.441550 & \\
\hline Prob (F-statistic) & 0.000471 & & & \\
\hline
\end{tabular}

Researcher's compilation from E-View (Version 9.0); Dependent variable: NP; Method: Least squares; Date: 10/12/18, Time: 23:31; Sample (adjusted): 2000-2018; Included observations: 15 after adjustments

Table 4: Breusch-Gsodfrey serial correlation LM test

\begin{tabular}{ll}
\hline Parameters & Values \\
\hline F-statistic & 0.224489 \\
$* \mathrm{R}^{2}$ & 1.235950 \\
Prob. F $(2,5)$ & 0.8066 \\
Prob. Chi-square (2) & 0.5390 \\
\hline
\end{tabular}

Researcher`s compilation from E-View (Version 9.0)

Error Correction Model (ECM): It has been pointed out that Error Correction Modeling (ECM) is meant to tie the short-run dynamics of the co-integrating equations to their long-run static dispositions in order to maintain equilibrium. In order to capture the short run fluctuation, the Error Correction Modeling (ECM) was employed and the result is presented below.

From Table 3, ECM (-1) was consistent by assuming negative values. It suggests that if in the short run variables deviate from equilibrium, they tend to re-adjust themselves back to equilibrium in the long run. The speed of this adjustment is $53 \%$ per annum. GPM had a positive and insignificant impact on NP. A unit increase in GPM leads to an increase in NP by 0.014131 units. From the estimation, we found that the operating margin had a significant positive impact on NP as it has a coefficient of 0.544606; this shows that a unit increase in OM resulted to an increase in NP by 0.544606 units. ROA had a coefficient of 0.432102 ; this shows that when returns on investment increase by I unit, the NP will increase by 0.432102 units. Returns of equity also had a statistically significant positive coefficient of 1.266759 which shows that a unit increase in ROA result to an increase in NP by 1.266759 units. Returns on sales had a negative and significant coefficient of -1.275197 ; this shows that when the returns on sales increases by 1 unit, NP will decreases by -1.275197 units and finally, returns on investment has a positive and statistically insignificant coefficient of 389.3445 it shows that when ROI is increased by 1 unit, NP increases by 389.3445 units. It can be deduced that in the long run if interest rate should increase by a percent; it will cause NP to decrease by approximately 389.3445
Table 5: Heteroskedasticity test: Breusch-Pagan-Godfrey

\begin{tabular}{ll}
\hline Parameters & Values \\
\hline F-statistic & 0.513000 \\
$* \mathrm{R}^{2}$ & 5.085919 \\
Scaled explained SS & 0.923248 \\
Prob. F(7, 7) & 0.8009 \\
Prob. Chi-square (7) & 0.6495 \\
Prob. Chi-square (7) & 0.9960 \\
\hline
\end{tabular}

Researcher's compilation from E-View (Version 9.0)

units. $\mathrm{R}^{2}=0.95$; this gives a good fit of the regression line it shows that $95 \%$ of the changes in dependent variables are caused by changes in the independent variables and the remaining $5 \%$ are as a result of variables not included in the model but captured by the contemporaneous error $(\mu)$.

LM serial correlation test: The LM serial correlation test is a test of auto correlation which was conducted to verify the presence of auto correlation among the variables employed in the study, the results is presented and discussed as below (Table 4):

From the result above it could be seen that the F-statistics 0.224489 has a probability value of 0.8066 which is $>0.05$, also the *R-squared had a coefficient of 1.235950 and a $p$-value of 0.5390 . Since, the $p$-values of both the f-statistics and the *R-squared were $>0.05$ level of significance, the study thus, conclude that there is no auto correlation in the series. Hence, the results obtained can be employed for forecasting purposes.

The Table 5 above, it could be seen that the *R-squared and the F-statistics had a p-value that is $<0.05$ level of significance as such the null hypothesis of heteroskedasticity among the series is rejected.

From the outcome of the results in Table 4 and 5, the study concludes that the result obtained can be relied upon as they conform to the assumptions of ordinary least square with special emphasis on assumptions 3 and assumption 4 of OLS which is the assumption of no auto correlation among the series and the assumptions of homoskedasticity in the series. 
Int. Business Manage., 13 (9): 371-380, 2019

\section{Test of hypothesis I:}

- $\mathrm{H}_{01}$ : there is no significant relationship between Gross Profit Margin (GPM) and the corporate profitability of selected oil companies in Nigeria

- $\mathrm{H}_{\mathrm{A} 1}$ : there is a significant relationship between Gross Profit Margin (GPM) and the corporate profitability of selected oil companies in Nigeria

The result from the error correction model was employed to test the above hypothesis via the t-statistics. From Table 3, it could be seen that the t-statistics of the gross profit margin has a p-value of 0.6041 which was $>0.05$ level of significance. Hence, the null hypothesis is accepted that there is no significant relationship between Gross Profit Margin (GPM) and the corporate profitability of selected oil companies in Nigeria.

\section{Test of hypothesis II:}

- $\mathrm{H}_{02}$ : there is no significant relationship between Operating Margin (OM) and the corporate profitability of selected oil companies in Nigeria

- $\mathrm{H}_{\mathrm{A} 2}$ : there is a significant relationship between Operating Margin (OM) and the corporate profitability of selected oil companies in Nigeria

To test the null hypothesis stated above, the t-statistics of operating margin in the ECM result was employed. The Table 4 shows that the t-statistics had a p-value of 0.0208 which was $<0.05$ level of significance. Thus, the null hypothesis is rejected; as such the alternate hypothesis is accepted that there is a significant relationship between Operating Margin (OM) and the corporate profitability of selected oil companies in Nigeria.

\section{Test of hypothesis III:}

- $\mathrm{H}_{03}$ : there is no significant relationship between Return on Assets (ROA) and the corporate profitability of selected oil companies in Nigeria

- $\mathrm{H}_{\mathrm{A} 3}$ : there is a significant relationship between Return on Assets (ROA) and the corporate profitability of selected oil companies in Nigeria

In testing the null hypothesis the study employed the t-statistics of return on assets from the ECM result. The Table 4 shows that the $t$-statistics had a p-value of 0.0160 which was $<0.05$ level of significance. Thus, the null hypothesis is rejected; as such the alternate hypothesis is accepted that there is a significant relationship between Return on Assets (ROA) and the corporate profitability of selected oil companies in Nigeria.

\section{Test of hypothesis IV:}

- $\mathrm{H}_{04}$ : there is no significant relationship between Return on Equity (ROE) and the corporate profitability of selected oil companies in Nigeria

- $\mathrm{H}_{\mathrm{A} 4}$ : there is a significant relationship between Return on Equity (ROE) and the corporate profitability of selected oil companies in Nigeria

To test the null hypothesis stated above, the result from the ECM test was employed. The Table 4 shows that the t-statistics of return on equity had a p-value of 0.0029 which was $<0.05$ level of significance. Thus, the null hypothesis is rejected; as such the alternate hypothesis is accepted that there is a significant relationship between Return on Equity (ROE) and the corporate profitability of selected oil companies in Nigeria.

\section{Test of hypothesis V:}

- $\mathrm{H}_{05}$ : there is no significant relationship between Return on Investment (ROI) and the corporate profitability of selected oil companies in Nigeria

- $\mathrm{H}_{\mathrm{A} 5}$ : there is a significant relationship between Return on Investment (ROI) and the corporate profitability of selected oil companies in Nigeria

To test the null hypothesis stated above, the result from the ECM test was employed. The Table 4 shows that the t-statistics of return on investment had a p-value of 0.8736 which was $>0.05$ level of significance. Thus, the null hypothesis is accepted and the study concludes that there is no significant relationship between Return on Investment (ROI) and the corporate profitability of selected oil companies in Nigeria.

The study investigated empirical analysis of triple bottom line accounting on the corporate profitability of ten selected oil companies in Nigeria for the period between 2000 and 2018, employing various techniques of econometric analysis such as the unit root test for stationarity of the series, the cointegration test for long run relationship within the series, the vector error correction model, the serial correlation test for auto correlation and the heteroskedasticity. In the course of the study, the objectives were to assess the relationship between Gross Profit Margin (GPM) and the corporate profitability of selected oil companies in Nigeria, evaluate the relationship between Operating Margins (OM) and the corporate profitability of selected oil companies in Nigeria, examine the relationship between Return on Assets (ROA) and the corporate profitability of selected oil companies in Nigeria, analyze the relationship between Return on Equity (ROE) and finally, highlight the 
relationship between the Return on Investment (ROI) and the corporate profitability of the selected oil companies in Nigeria.

On the application of advanced econometric techniques (Augmented Dickey Fuller, Johansen Cointegration Test and Error Correction Mechanism), the following information were extracted; none of the variables was stationary at zero level using augmented dickey fuller unit root test. This means they all have unit roots; However, all of the variables became stationary after first differencing which necessitates the application of Johansson cointegration test to test for long run relationship.

The Johansson cointegration test which was used to test the null hypothesis of no long-run relationship reveals at least four co-integrating equation between the variables employed which were proxies for triple bottom line accounting and corporate profitability which was proxied as net profit. This implies that there is a long-run relationship between triple bottom line accounting and corporate profitability. To ascertain the significant relationship between triple bottom line accounting and corporate profitability, the study made use of Error Correction Mechanism (ECM). The result from the ECM indicates that operating margin, gross profit margin, returns on assets, returns on investment and returns on equity had a positive and significant relationship with net profit while returns on sales had a negative and significant relationship with net profit.

The result was also verified not to violate the twin problem of endogenity and auto correlation as the Breusch-Godfrey serial correlation LM test and the Breusch-Pagan-Godfrey test for heteroskedasticity revealed that the series is devoid of autocorrelation and heteroskedasticity.

Finally, the regression result indicates that the coefficient of determination $\left(\mathrm{R}^{2}\right)$ was 0.95 . This shows that the explanatory variables account for $95 \%$ of the total variations in net profit during the period under consideration while the remaining $5 \%$ were not accounted for by the explanatory variables but captured by the error term. The F-statistics which is the test for joint influence from the ECM result revealed that the explanatory variables have joint influence on the dependent variable.

Summary of findings: Evidence from the study portrays that triple bottom line accounting ensures the availability of a framework which enables companies to create value for all levels of stakeholders which in turn translates to meeting the diverse interest of the various stakeholders. This is the thrust of stakeholder theory which emphasizes the need for managers to adopt management approach which showcases the willingness and commitment of the firms towards pursuing and attaining the good of all stakeholders. Based on the results obtained from data analysis, the findings of the study can be summarized thus;

- The non-existence of a significant relationship between Gross Profit Margin (GPM) and the corporate profitability of selected oil companies in Nigeria

- The existence of a significant relationship between Operating Margin (OM) and the corporate profitability of selected oil companies in Nigeria

- The existence of a significant relationship between Return on Assets (ROA) and the corporate profitability of selected oil companies in Nigeria

- The existence of a significant relationship between Return on Equity (ROE) and the corporate profitability of selected oil companies in Nigeria

- The non-existence of a significant relationship between Return on Investment (ROI) and the corporate profitability of selected oil companies in Nigeria

\section{CONCLUSION}

On a general note it can be observed from this study that triple bottom line accounting as a concept lays emphasizes on the need for businesses to adopt sustainable use of her business environment and also to embark on practices which enables her to meet the various interest of the stakeholders as a survival strategy. The study while employing various techniques of econometric analysis discovered the existence of a long-run relationship between triple bottom line accounting and corporate profitability proxied by net profit.

\section{SUGGESTIONS}

This suggests that, when companies are socially, environmentally and economically responsible to their host community or business environment, they stand the chance of enjoying an increase in profit. This may be largely to so many reasons, ranging from the increased acceptance they will receive from the people, to the creation of a stable, peaceful and chaos free business atmosphere which remains a critical factor towards corporate survival and successful business operations. Also, imbibing the notion of the triple bottom line enables firms to cut down cost of operation as the firm spends less money on the settlement of fines and compensation as a result of her irresponsible behavior. 


\section{RECOMMENDATIONS}

This study recommends the introduction of triple bottom line reporting into compulsory continuing professional education schemes and programs of professional accountancy bodies. As it has remained a contemporary issue in accounting development world over. Hence, professional accountancy bodies in Nigeria should take due advantage of the trend by making it one of the compulsory programs in continuing professional education.

Companies operating in Nigeria, oil companies inclusive, should adopt triple bottom line reporting initiatives, as this enables them to identify, apportion and appraise ecological and social costs affecting their various businesses and also, enable managers to acquire strategies and techniques which are needed in the management of corporate organization's ecological, social and economic performance.

There is a need for the host communities of firms, especially, oil companies and other stakeholders and well as governmental and non-governmental agencies to request for triple bottom line reports which should meet their need for information, thus, enabling them to be in a better position to hold companies to account for not for all the dimensions of triple bottom lines.

Contribution to knowledge: The knowledge provided by this study will contribute significantly to theoretical justification and provide improved body of literature on the concept of triple bottom line accounting and sustainability reporting.

This study will be of immerse benefit to the government, regulatory authorities, non-governmental organizations, oil and gas companies, other corporate organizations, researchers/research bodies and the society at large. This study has provided an enviable empirical validation which proved that triple bottom line accounting is of utmost importance to all levels of stakeholders and if triple bottom line reporting system is consolidated and embarked upon then there will be tremendous and significant impact on the corporate profitability of oil companies in Nigeria.

\section{ACKNOWLEDGEMENT}

First and foremost, I would want to appreciate my supervisor Dr. Emengini SE of the Accountancy Department University of Nigeria, Nsukka. Dr. Emengini's door was continually open whenever I needed his assistance in any aspect of this research work. I also would want to express my profound gratitude to my dear husband, Dr, Onuoha SE for his unwavering support and encouragement throughout the process of this research work. Finally, my immense gratitude goes to my parents, my kids and my siblings for their various contributions through out the cause of this study. This milestone would not have been possible without each and every one of them.

\section{REFERENCES}

Beretta, S. and S. Bozzolan, 2004. Reply to: Discussions of a framework for the analysis of firm risk communication. Int. J. Accounting, 3: 303-305.

Elkington, J., 1997. Cannibals with Forks: The Triple Bottom Line of 21st Century Business. New Society Publishers, Gabriola Island, Canada.

Hammer, J. and G. Pivo, 2017. The triple bottom line and sustainable economic development theory and practice. Econ. Dev. Q., 31: 25-36.

Ho, L.C.J. and M.E. Taylor, 2007. An empirical analysis of triple bottom-line reporting and its determinants: Evidence from the United States and Japan. J. Int. Fin. Manage. Accounting, 18: 123-150.

Hubbard, G., 2008. Beyond accounting-assessing the impact of sustainability reporting on tomorrow's business. MBA. Thesis, University of Adelaide Business School, Adelaide, Australia.

Ijeoma, N.B., 2014. Assessing the impact of triple bottom line reporting on problem of corporate sustainability in Nigeria. Am. J. Serv. Sci. Manage., 1: $10-16$.

King, R. and C. Levine, 2004. Financial indicator and economic growth in a cross section of countries. Pre-Working Paper No. 819, World Bank, Washington, USA.

Kwaghfan, A., 2015. Impact of sustainability reporting on corporate performance of selected quoted companies in Nigeria. Ph.D. Thesis, University of Nigeria. Nsukka, Nigeria.

Lassala, C., A. Apetrei and J. Sapena, 2017. Sustainability matter and financial performance of companies. Sustainability, Vol. 9, No. 9. 10.3390/su9091498

Ndukwe, A.G.A., 2009. Corporate risk reporting practices and their determinants. A study of selected quoted firms in Nigeria. Nigeria Res. J. Accountancy, 1: 81-94.

Savitz, A.W., 2006. The Triple Bottom Line: How Today's Best-Run Companies are Achieving Economic, Social and Environmental Success and How You can Too. Wiley, Hoboken, New Jersey, ISBN:9780787986490, Pages: 288.

Suttipun, M., 2012. Triple bottom line reporting in annual reports: A case study of companies listed on the Stock Exchange of Thailand (SET). Asian J. Finance Accounting, 4: 69-92. 